\title{
Riceland Spiders of South and Southeast Asia
}

\author{
A T Barrion and J A Litsinger, Entomology Division, International Rice Research Institute, Philippines
}

Spiders are among the most omnipresent and numerous predators in both agricultural and natural ecosystems, and without them insect pest populations would become out of control. Their potential as biological control agents can only be appreciated through a greater understanding of their abundance and species composition in different ecological systems. There is therefore a great need for literature providing guidance on spider identification.

The spider fauna of several cultivated crops, in a number of regions of the world, has been well documented. There have been some previous attempts to record the spider fauna of rice in South and Southeast Asia, but these are scattered in the journal literature. This volume provides a comprehensive illustrated guide that can be used by specialists and novices to identify these spiders. The majority of the species covered were collected from a diversity of habitats in the Philippines. The bulk of the book consists of keys to the identification of families, genera and species of Philippine spiders, illustrated by more than 1000 line drawings and 100 colour photographs. A total of 339 species belonging to 134 genera within 26 families are recognized. Of these, 253 species and seven genera are new to science. Distribution maps for individual species and a classification scheme for Philippine riceland spiders are also provided. Overall, the work represents a major contribution to the literature for those interested in spiders or more generally in biological control and crop protection.

\section{Contents:}

- Historical background

- External anatomy

Cephalothorax • Eyes • Mouthparts • Pedipalps • Maxille $\bullet$ Labium $\bullet$ Sternum $\bullet$ Legs $\bullet$ Abdomen

- Life History

- Materials and Methods

Collection sites - Sampling techniques - Perservation of specimens - Photographing and preparation for illustrations - Classification - Measurements • Rearing methods

- Classification of the spider families Order Araneae

- A key to identification of families of Philippine spiders

- Descriptions

Key to the uloborid genera and species

Key to the pholcid genera and species

Key to the salticid genera and species

Key to the clubionid genera and species

Key to the gnaphosid genera and species

Key to the thomisid genera and species

Key to the eusparassid genera and species

Key to the mimetid genera and species

Key to the genera and species of ant-eating spiders

Key to the genera and species of lynx spiders Key to the genera and species of nursery web spiders Key to the genera and species of wolf spiders Key to the genera and species of comb-footed spiders Key to the genera and spedies of sheet-web spiders Key to the genera and species of long-jawed spiders Key to the genera and species of metid spiders Key to the genera and species of araneid spiders

- Common relatives of spiders

- Spider diversity in Philippine rice environments

- Distribution maps of riceland spiders

- Colored plates of some common spiders

Readership: Those interested in spiders or more generally in biological control and crop protection.

September 1995

ISBN 0851989675

736 pages

HB

Price: $£ 125.00$ (US $\$ 225.00$ Americas only)

For further information or to order please contact CAB INTERNATIONAL headquarters or an exclusive CAB INTERNATIONAL distributor in your area.

Please add $£ 2.00$ per book postage and packing (excluding $U K$ ).

\section{CAB INTERNATIONAL}

Headquarters, Wallingford, Oxon OX10 8DE, UK. Tel: (01491) 832111 Telex: 847964 (COMAGG G) Fax: (01491) 833508 E-mail: cabi@cabi.org

North America, 845 North Park Avenue, Tucson, Arizona 85719, USA. Tel: 800/528-4841 520/621-7897) Fax: 520/621-3816 E-mail: cabi-nao@cabi.org

Africa, PO Box 76520, Nairobi, Kenya. Tel: Nairobi 747 340/337 Telex: 22040 ILRAD (KE) (for IBC Muguga) Fax: Nairobi 747 340 E-mail: cabi-iibc-kenya@cabi.org

Asia, PO Box 11872, 50760 Kuala Lumpur, Malaysia. Tel: (03) 2552922 Telex: 28031 (MA CABI) Fax (03) 255188 E-mail: cabi-aro@cabi.org

Carribean, Gordon Street, Curepe, Trinidad and Tobago. Tel: 8096624173 Telex: 24438 (CARIRI) Fax: 8096632859 E-mail: cabi-crowcabi.org 


\title{
Medical and Veterinary Entomology, 2nd Edition
}

\author{
D S Kettle, Emeritus Professor, Department of Entomology, \\ University of Queensland, Australia
}

The first edition of this book, published in 1984, established itself internationally as a standard text in medical and veterinary entomology. This new edition retains the same overall aims and structure but has been thoroughly revised to take account of new advances in the subject.

The main focus of the book is on the general biology of insects and the Acari (mites and ticks) of medical and veterinary importance, together with brief descriptions of their taxonomy and of the treatment of diseases they cause. The book consists of 32 chapters and is divided into three parts: the first provides a general introduction to the classification, structure and function of the relevant insects and Acari; the second covers, in seventeen chapters, the main groups of insects and acarines of medical and veterinary importance, from the Culicidae (mosquitoes) to the Ixodidae (hard ticks); part three then provides an overview of those diseases of which the pathogens are transmitted by insects or acarines.

\section{Contents:}

Part I: General introduction to medical and veterinary entomology

Part II: Insects and acarines of medical and veterinary importance

Part III: Diseases of which the pathogens are transmitted by insects of acarines

From reviews of the first edition:

'This is an important and comprehensive account of pests and vectors attacking man and his livestock...an excellent book that will remain a standard reference source that I, and I am sure many others, will use for a long time.'

M W Service, Annals of Tropical Medicine and Parasitology

'...the work must be regarded as a classic text book of its kind, and an invaluable reference book for both pure entomology and the parasitology of arthropod-borne pathogens.'

N R H Burgess, International Pest Control

'...if only one general reference book on medical and veterinary entomology can be afforded by either a library or an individual, then it should be this.'

R P Lane, Entomologist's Monthly Magazine

'...from time to time books are published that make one wish they had appeared at a much earlier stage in one's working life. This book is one of them!

M T Gillies, International Journal of Epidemiology

Readership: A major reference text for students taking courses in zoology, tropical medicine, veterinary science, entomology and parasitology, as well as for professionals working in both pure and applied entomology.
October 1995
720 pages
$\mathrm{HB} / \mathrm{PB}$
ISBN $0851989683 \mathrm{HB}$ Price: $€ 75.00$ (US\$135.00 Americas only)
ISBN 0851989691 PB Price: $€ 37.50$ (US\$70.00 Americas only)

For further information or to order please contact CAB INTERNATIONAL headquarters or an exclusive CAB INTERNATIONAL distributor in your area.

Please add $£ 2.00$ per book postage and packing (excluding UK).

\section{CAB INTERNATIONAL}

Headquarters, Wallingford, Oxon OX10 8DE, UK. Tel: (01491) 832111 Telex: 847964 (COMAGG G) Fax: (01491) 833508 E-mail: cabi@cabi.org North America, 845 North Park Avenue, Tucson, Arizona 85719, USA. Tel: 800/528-4841 520/621-7897) Fax: 520/621-3816 E-mail: cabi-nao@cabi.org Africa, PO Box 76520, Nairobi, Kenya. Tel: Nairobi $747340 / 337$ Telex: 22040 ILRAD (KE) (for IlBC Muguga) Fax: Nairobi 747340 E-mail: cabi-iibc-kenya@cabi.org Asia, PO Box 11872, 50760 Kuala Lumpur, Malaysia. Tel: (03) 2552922 Telex: 28031 (MA CABI) Fax (03) 255188 E-mail: cabi-aro@cabi.org

Carribean, Gordon Street, Curepe, Trinidad and Tobago. Tel: 8096624173 Telex: 24438 (CARIRI) Fax: 8096632859 E-mail: cabi-cro@cabi.org 


\section{Insect Pests of Cotton}

\section{Edited by G Matthews, Imperial College at Silwood Park, Ascot, UK, and J Tunstall}

This major work provides a comprehensive review of the biology and pest status of insects known to infect cotton throughout the world.

\section{Contents}

Part I The Cotton Plant

Cotton and its Production, J Munro

Part II Insects and Mites

Insect and Mite Pests: General Introduction, G A Matthews

Heliothis/Helicoverpa (Lepidoptera: Noctuidae), A B S King

Pectinophora (Lepidoptera: Galechiidae), WR Ingram

Earias Spp. (Lepidoptera: Noctuidae), W Reed

Diparopsis Spp. (Lepidoptera: Noctuidae), J P Tunstall

Cryptophlebia (Lepidoptera: Tortricidae), $R$ Couilloud

Other Lepidoptera, G A Matthews

Anthonomus (Coleoptera: Curculionidae), J W Smith and F A Harris

Other Coleoptera, SW Broodryk and G A Matthews

Dysdercus (Hemiptera: Pyrrhocoridae) and other Heteroptera, $S$ W Broodryk and G A Matthews

Aphids (Hemiptera: Aphididae), F Leclant and J P Deguine

Bemisia and Trialeurodes (Hemiptera: Aleyrodidae), GD Butler and T J Henneberry

Jassids (Hemiptera: Cicadellidae), G A Matthews

Paurocephala gossypii Russell (Homoptera: Psyllidae), G K C Nyirenda

Lygus (Hemiptera: Miridae) and other Hemiptera, T Leigh and G A Matthews

Thysanoptera, I P Bournier

Orthoptera, G A Matthews

Isoptera, I K M Logan

Acari - leaf feeding mites, J Gutierrez

Part III Pest Management

The Effects of Insect Attack on the Yield of Cotton, G A Matthews

Breeding for Insect Resistance, J R Gannaway

Cultural Control, G A Matthews

Biological Control, D J Greathead

Use of Baculoviruses for Cotton Pest Control, K A Jones

Phermones for the Control of Cotton Pests, D G Campion

Chemical control, G A Matthews

Pest Management Systems, J D Mumford and G A Norton

June 1994592 pages Hardback 44 Colour plates

ISBN 0851987249

Price: $£ 82.50$ (US $\$ 150.00$ Americas only)

For further information or to order please contact CAB INTERNATIONAL headquarters or an exclusive CAB INTERNATIONAL distributor in your area.

Please add $£ 2.00$ per book postage and packing (excluding $U K$ )

Headquarters

CAB INTERNATIONAL

Wallingford

Oxon OX10 8DE,

UK

Tel: (01491) 832111

Fax: (01491) 833508
North America

University of Arizona Press

1230 North Park Avenue, Suite 102

Tucson, Arizona 85719-4140

USA

Tel: (602) 8823065

Fax: (602) 6218899
Singapore and Malaysia

Publishers Marketing Services

10-C Jalan Ampas \#07-01

Ho Seng Lee Flatted Warehouse

Singapore 1232

Tel: (65) 2565166

Fax: (65) 2530008
Australasia

DA Books

648 Whitehorse Road

Mitcham 3132, Victoria

Australia

Tel: (3) 8734411

Fax: (3) 8735679 


\title{
The Scale Insect Family Coccidae: An Identification Manual to Genera
}

\author{
C J Hodgson, Department of Biological Sciences, \\ Wye College, University of London, UK
}

The soft-scales (Coccidae) are one of about 20 families of the scale insect superfamily Coccoidea. The females are all sap-sucking and all 1100 known species are potential pests in agriculture, horticulture or forestry. This family is amongst the most poorly known although the third largest in the superfamily. This book discusses all known genera and redescribes and illustrates the adult females of the type species of about 160 soft scale genera. No previous revision has covered all world genera. On the basis of this study a new classification of the soft-scales is introduced based on both male and female characters and keys are provided to the identification of the type species (females) of each genus. An introductory chapter describes the basic structure and introduces the terminology. As the females of all Coccoidea are of potential economic importance, this book will be of value to any entomologist who needs to identify soft-scales either for quarantine or for research involving natural enemies for biological control.

\section{Contents}

Morphology and terminology

Introduction

Illustrations

General external structure

Host-induced differences

Appearance of unmounted material

Mounted material

Structure of dorsum

Marginal structures

Structure of venter

Instar indentification

Other information

\section{Classification}

Short history of classification of the family

Coccidae

Introduction

Family Coccidae

Subfamily Cardiococcinae

Subfamily Ceroplastinae

Subfamily Cissococcinae

Subfamily Coccinae

Tribe Coccini

Tribe Paralecaniini
Tribe Pulvinariini

Tribe Saissetiini

Subfamily Cyphococcinae

Subfamily Eulecaniinae

Subfamilies Eriopeltinae and Filippiinae

Subfamily Myzolecaniinae

Subfamily Pseudopulvinariinae

Unplaced Genera

List of genera and type species

Keys to subfamilies, tribes and genera

Key to subfamilies and tribes

Key to genera in the Cardiococcinae

Key to genera in the Ceroplastinae

Key to genera in the Coccini

Key to genera in the Paralecaniini

Key to genera in the Pulvinariini

Key to genera in the Saissetiini

Key to genera in the Cyphococcinae

Key to genera in the Eulecaniinae

Key to genera in the Eriopeltinae + Filippiinae

Key to genera in the Myzolecaniinae

Descriptions of type species
April 1994
672 pages
Hardback

ISBN 0851988822

Price: $£ 82.50$ (US\$150.00 Americas only)

For further information or to order please contact CAB INTERNATIONAL headquarters or an exclusive CAB INTERNATIONAL distributor in your area.

Please add $£ 2.00$ per book postage and packing (excluding $U K$ )

$\begin{array}{lll}\text { Headquarters } & \text { North America } & \text { Singapore and Malaysia } \\ \text { CAB INTERNATIONAL } & \text { University of Arizona Press } & \text { Publishers Marketing Services } \\ \text { Wallingford } & \text { 1230 North Park Avenue, Suite 102 } & \text { 10-C Jalan Ampas \#07-01 } \\ \text { Oxon OX10 8DE, } & \text { Tucson, Arizona 85719-4140 } & \text { Ho Seng Lee Flatted Warehouse } \\ \text { UK } & \text { USA } & \text { Singapore } 1232 \\ \text { Tel: (01491) 832111 } & \text { Tel: (602) 882 3065 } & \text { Tel: (65) 256 5166 } \\ \text { Fax: (01491) 833508 } & \text { Fax: (602) 621 8899 } & \text { Fax: (65) 2530008 }\end{array}$

Headquarters

Wallingford

UK

Fax: (01491) 833508
Australasia

DA Books

648 Whitehorse Road

Mitcham 3132, Victoria

Australia

Tel: (3) 8734411

Fax: (3) 8735679 


\title{
Host Plant Resistance to Insects
}

\author{
N Panda, former Professor of Entomology, Orissa University of Agriculture and \\ Technology, India, and GS Khush, Principal Plant Breeder, International Rice \\ Research Institute, Philippines
}

The overuse and misuse of insecticides some four decades ago created major environmental problems and was followed by the development of an 'integrated pest management' approach to crop pests. This approach utilizes a combination of host plant resistance and cultural, biological and chemical control methods. Crop improvement programs emphasize the breeding of crop varieties with multiple resistance to pests, and resistant varieties developed in recent years represent some of the greatest achievements of modern agriculture.

This book presents a broad overview of host plant resistance to insect pests. It shows how plants can defend themselves naturally and how insects have adapted to overcome these mechanisms through coevolution. It also describes screening and breeding for insect resistance.

\section{Contents:}

- $\quad$ Foreword by G Rothschild

- Introduction

- $\quad$ Crop plant and insect diversity

- Secondary plant metabolites for insect resistance

- Insect-plant interactions

- Host plant selection

- Mechanisms of resistance

- Factors affecting expression of resistance

- $\quad$ Screening for insect resistance

- Plant resistance and insect pest management

- Genetics of resistance to insects

- Breeding for resistance to insects

Readership: A major advanced textbook for entomologists, plant breeders and those concerned with crop protection.

July 1995

ISBN 0851989632

Price: $£ 55.00$ (US\$99.00 Americas only)

For further information or to order please contact CAB INTERNATIONAL headquarters or an exclusive CAB INTERNATIONAL distributor in your area. Please add $£ 2.00$ per book postage and packing (excluding UK).

CAB INTERNATIONAL

Headquarters, Wallingford, Oxon OX10 8DE, UK. Tel: (01491) 832111 Telex: 847964 (COMAGG G) Fax: (01491) 833508 E-mail: cabi@cabi.org North America, 845 North Park Avenue, Tucson, Arizona 85719, USA. Tel: 800/528-4841 520/621-7897) Fax: 520/621-3816 E-mail: cabi-nao@cabi.org Africa, PO Box 76520, Nairobi, Kenya. Tel: Nairobi 747 340/337 Telex: 22040 ILRAD (KE) (for IIBC Muguga) Fax: Nairobi 747340 E-mail: cabi-iibc-kenya@cabi.org Asia, PO Box 11872, 50760 Kuala Lumpur, Malaysia. Tel: (03) 2552922 Telex: 28031 (MA CABI) Fax (03) 255188 E-mail: cabi-aro@cabi.org

Carribean, Gordon Street, Curepe, Trinidad and Tobago. Tel: 8096624173 Telex: 24438 (CARIRI) Fax: 8096632859 E-mail: cabi-cro@cabi.org 


\section{NOTES FOR AUTHORS}

The Bulletin of Entomological Research publishes original research papers concerning insects, mites, ticks or other arthropods of economic importance in agriculture, forestry, stored products, biological control, medicine, animal health and natural resource management. The geographical scope of the Bulletin is worldwide but with emphasis on the tropics. Taxonomic papers are accepted if relevant. Short review papers, although normally by invitation, will also be considered for publication.

Page Format. The Bulletin is printed in a two-column format (column width of $80 \mathrm{~mm}$ ) with a text area of $170 \times 225 \mathrm{~mm}$.

Text. Papers should be typed, on one side of the paper only, with double line spacing and ample margins (at least $1.5 \mathrm{~cm}$ ) on each side and with no underlining or bold in text except for scientific names. Draft quality print from a word-processor is not acceptable. Standard abbreviations (e.g. fig. and figs) and metric units must be used. Guidelines for taxonomic papers are available.

When the paper has been accepted word-processed text stored on floppy disk is encouraged, providing the software is IBM/DOS compatible, but floppy discs must be accompanied by a hard copy. This will enable papers to be handled rapidly, and with fewer type-setting errors.

Abstract. Each paper must commence with a carefully prepared, accurate, informative abstract, in one paragraph, that is complete in itself and intelligible without reference to text or figures. It should not exceed 250 words. A short title should be provided as a running head.

Tables. Tables should be reduced to the simplest form, and should not be used where text or illustrations give the same information. They should be submitted on separate sheets at the end of the article and must fit conveniently into single column, full width or landscape (if absolutely necessary) format. Table captions should be typed on a separate sheet.

Illustrations. Copies only of artwork should be submitted. The original illustrations should accompany the paper after acceptance and revision. Text figures, line drawings, computer-generated figures and graphs should be of sufficient size and quality to allow for reduction by half or two-thirds. Half-tone photographs are acceptable where they are a real contribution to the text. Figure and captions should be typed on a separate sheet in the following format:

Figs 23-26. Figs 23-24, Urophora eggs: 23, $\underline{U}$ hispanica; 24 U. stigma. Figs $25-26$, spermathecae: 25 , U. maura; 26 , U. stigma; scale lines $=0.05 \mathrm{~mm}$.

Voucher specimens. The deposition of voucher specimens should be considered where appropriate.

References. References must be based on the name and year system, give full journal titles and conform to the following styles:

Powell, W. (1986) Enhancing parasitoid activity in crops. pp. 319-340 in Waage, J. \& Greathead D. (Eds) Insect parasitoids. London, Academic Press (Symposium, Royal Entomological Society of London No. 13).

Southwood, T.R.E. (1978) Ecological methods with particular reference to the study of insect populations. 2nd edn. 524 pp. London, Chapman \& Hall.

Zhou, X., Carter, N. \& Mumford, J. (1989) A simulation model describing the population dynamics and damage potential of the rose grain aphid, Metopolophium dirhodum (Walker) (Hemiptera: Aphididae), in the UK. Bulletin of Entomological Research 79, 373-380.

Citation of authors in the text should appear in the form: Polaszek (1990) or (Polaszek, 1990). More than one author should be cited in chronological order as: (Holloway et al., 1987; Walker \& Huddleston, 1988).

Offprints. 50 copies of each paper are provided free to the author (or major author) of each paper. Further copies may be obtained on payment, and the number required should be specified and ordered at proof stage.

Manuscripts. Three copies of the manuscript and artwork should be submitted to:

The Editor

Bulletin of Entomological Research

International Institute of Entomology

56. Queen's Gate

London

SW7 5JR, UK. 


\section{Bulletin of Entomological Research}

Cork, A. \& Basu, S.K. Control of the yellow stem borer, Scirpophaga incertulas, by mating disruption with a PVC resin formulation of the sex pheromone of Chilo suppressalis (Lepidoptera: Pyralidae) in India

Dougherty, M.J. \& Hamilton, J.G.C. A biologically-active compound from pupae of the sandfly Lutzomyia longipalpis (Diptera: Psychodidae) and its possible role in defence.

Foster, S.P., Harrington, R., Devonshire, A.L., Denholm, I., Devine, G.J., Kenward, M.G. \& Bale, J.S. Comparative survival of insecticide-susceptible and resistant peach-potato aphids, Myzus persicae (Sulzer) (Hemiptera: Aphididae), in low temperature field trials

Gurusubramanian, G. \& Krishna, S.S. The effects of exposing eggs of four cotton insect pests to volatiles of Allium sativum (Liliaceae)

Mihok, S., Moloo, S.K., Oden'y, J.O., Brett, R.A., Rakwar, J.G., Munyoki, E., Kiilu, J. \& Kyorku, C.A. Attractiveness of black rhinoceros (Diceros bicornis) to tsetse flies (Glossina spp.) (Diptera: Glossinidae) and other biting flies

Montoya-Lerma, J. \& Lane, R.P. Factors affecting host preference of Lutzomyia evansi (Diptera: Psychodidae), a vector of visceral leishmaniasis in Colombia

Pijls, J.W.A.M. \& Alphen, J.J.M. van On the coexistence of the cassava mealybug parasitoids Apoanagyrus diversicomis and A. lopezi (Hymenoptera: Encyrtidae) in their native South America.

Roberts, D.M. Circadian flight activity of Arabian sandflies (Diptera: Psychodidae) using a vehicle-mounted net.

Shishehbor, P. \& Brennan, P.A. Parasitism of the castor whitefly, Trialeurodes ricini (Homoptera: Aleyrodidae) by Encarsia formosa (Hymenoptera: Aphelinidae): bionomics in relation to temperature

Surekha, K., LaSalle, J., Sudheendrakumar, V.V. \& Murphy S.T. A new species of Sympiesis (Hymenoptera: Eulophidae) parasitic on the teak defoliator Hyblaea puera (Lepidoptera: Hyblaeidae) in India.

Waller, D.A. Ampicillin, tetracycline and urea as protozoicides for symbionts of Reticulitermes flavipes and $R$. virginicus (Isoptera: Rhinotermitidae).

Short Communication

Adda, C., Borgemeister, C., Meikle, W.G., Markham, R.H., Olaleye, I., Abdou, K.S. \& Zakari, M.O. First record of the larger grain borer, Prostephanus truncatus (Coleoptera: Bostrichidae), in the Republic of Niger 